\title{
PENGEMBANGAN KOMIK DIGITAL MENGENAI PELECEHAN \\ SEKSUAL SECARA VERBAL (CATCALLING) MELALUI BIMBINGAN KLASIKAL PADA PESERTA DIDIK SMAN 59 JAKARTA
}

\author{
Ghina Aninda Dwiputri ${ }^{1}$ \\ Wirda Hanim²
}

\begin{abstract}
Abstrak
Latar belakang dari penelitian ini adalah kurangnya pengetahuan peserta didik mengenai pelecehan seksual secara verbal (catcalling), maka dari itu, diperlukan sebuah produk yang tepat agar dapat membantu peserta didik dalam meningkatkan pengetahuannya. Komik digital merupakan salah satu media pembelajaran yang digunakan untuk meningkatkan pengetahuan peserta didik mengenai pelecehan seksual secara verbal (catcalling). Tujuan dari penelitian ini adalah mengembangkan komik digital mengenai pelecehan seksual secara verbal (catcalling) melalui bimbingan klasikal pada peserta didik SMAN 59 Jakarta. Metode yang digunakan adalah Research and Development $(\mathrm{R} \& \mathrm{D})$ dengan langkah-langkah meliputi analisis potensi dan masalah, mengumpulkan informasi, desain produk, dan validasi desain, serta menggunakan tahapan pengembangan model instruksional ADDIE (Analyze, Design, Development, Implementation, Evaluation). Hasil dari uji validitas dengan ahli media mendapat hasil sebesar 74\% (Layak) dan dengan ahli materi mendapat hasil sebesar 90\% (Sangat Layak). Hasil uji coba penilaian media terhadap kelompok kecil mendapat hasil sebesar 87\% (Sangat Layak) dan uji coba ketercapaian tujuan instruksional mendapat hasil sebesar 87\% (Sangat Layak). Sehingga, komik digital mengenai pelecehan seksual secara verbal (catcalling) yang dikembangkan oleh peneliti mendapat hasil keseluruhan sebasar 83,67\% dan dinyatakan "Sangat Layak". Kata Kunci: Komik Digital, Pelecehan Seksual, Catcalling, Bimbingan Klasikal
\end{abstract}

\begin{abstract}
The background of this study is the lack of students' knowledge about verbal sexual harassment (catcalling), therefore, an appropriate product is needed in order to help students improve their knowledge. Digital comic is one the the learning media that can be used to improve students' knowledge about verbal sexual harassment (catcalling). This study aims to develop digital comic about verbal sexual harassment (catcalling) through classical guidance for students of 59 Senior High School Jakarta. The method used is Research and Development (R\&D) with steps include potential and problem analysis, data collection, product design, and design validation, also by using the stages of developing ADDIE instructional models (Analyze, Design, Development, Implementation, Evaluation). The results of the validity test with media experts reached $74 \%$ (Feasible) and the material experts reached $90 \%$ (Very Eligible). The results of the media evaluation trial of the small group reached $87 \%$ (Very Eligible) and a trial of the attainment of instructional goals reached $87 \%$ (Very Eligible). Thus, the results of digital comics about verbal sexual harassment (catcalling) developed by the researcher reached 83,67\% and can be categorized "Very Eligible".
\end{abstract}

Keywords: Digital Comic, Sexual Harassment, Catcalling, Classical Guidance

\footnotetext{
${ }^{1}$ Ghina Aninda Dwiputri, ghinaaninda17@gmail.com

${ }^{2}$ Wirda Hanim, whanim@unj.ac.id
} 

Pelecehan seksual bukanlah hal yang baru di lingkungan masyarakat. Supanto (2004) mengatakan bahwa pelecehan seksual dapat diartikan sebagai suatu perbuatan yang dilakukan seseorang atau sejumlah orang dengan orientasi seksual baik secara verbal maupun nonverbal, biasanya dilakukan oleh laki-laki terhadap perempuan dan tidak didasarkan dengan kesukarelaan. Sumera (2013) menjelaskan bahwa pelecehan seksual memiliki jangkauan yang sangat luas, mulai dari ungkapan verbal seperti memberikan siulan, komentar, dan gurauan yang tidak senonoh, hingga perilaku seperti mencolek, meraba, mengelus, mencium dan memeluk orang lain secara paksa.

Berbicara mengenai pelecehan seksual tentu di dalamnya terdapat berbagai macam pelecehan seksual, salah satunya adalah pelecehan seksual secara verbal. Bentuk pelecehan seksual secara verbal diantaranya berupa siulan, gurauan seks, komentar yang berkaitan dengan seksual, serta pernyataan yang bersifat mengancam (Harendza dkk., 2018). Dewasa ini, sebagian masyarakat mengenal hal tersebut dengan sebutan catcalling. Sebutan ini juga diperkuat dengan mengacu pada hasil penelitian yang dilakukan oleh Collen O'Leary pada tahun 2016 yaitu catcalling diartikan sebagai komentar berkonotasi seksual dan bersifat merugikan yang dilakukan oleh seorang atau sekelompok laki-laki terhadap perempuan di ruang publik, misalnya seperti tatapan mata yang memperlihatkan hasrat seksual (O'Leary, 2016). Bentuk pelecehan seksual ini cukup sering terjadi di jalanan dengan contoh seperti "Hey cantik, ikut abang, yuk!", "Neng, cemberut aja, senyum dong!", "Mau pergi ke mana, neng?Abang anter, yuk!", “*bersiul* Montok bener", "Hai, sexy!", "Halo manis, aku pesanin kamar, ya." dan lain sebagainya (Martin, 2018).

Priherdityo (2016) melalui CNN Indonesia melansir bahwa pada Juni 2016 Lentera Sintas Indonesia mencatat laporan Komnas Perempuan bahwa setiap harinya, terdapat 35 perempuan yang menjadi korban kekerasan seksual, dengan kata lain, dua dari tiga perempuan telah menjadi korban kekerasan seksual. Survei yang dilakukan secara anonimus daring oleh lembaga tersebut menyibak hal lainnya. Sebanyak 12.812 perempuan yang dijadikan sampel, $46,7 \%$ pernah mengalami kekerasan seksual, 28,6\% dari 12.382 responden laki-laki juga mengalami kekerasan seksual, lalu 83\% dari 12 responden transgender juga pernah menjadi korban kekerasan seksual. Lentera Sintas Indonesia mendefinisikan kekerasan seksual menurut Komnas Perempuan mencakup kekerasan secara verbal, fisik, pemaksaan melihat konten porno, intimidasi atau ancaman melakukan aktivitas seksual, serta pemerkosaan.

Maraknya kasus pelecehan seksual yang terjadi akhirnya melahirkan gerakan dan kampanye sosial tentang pelecehan seksual itu sendiri. Gerakan sosial yang dilakukan demi menaikkan kesadaran masyarakat tentang isu pelecehan seksual telah lama dilakukan di berbagai negara. Salah satunya di Indonesia, Women's March pertama diadakan pada 8 Maret 2017 di Jakarta. Sekitar 1.000 orang dengan pakaian berwarna merah jambu dan ungu berjalan menuju Istana Kepresidenan menuntut hak perempuan dan kesenjangan gender, serta untuk meningkatkan kesadaran masyarakat terhadap isu pelecehan seksual. Selain gerakan sosial dengan turun di jalan, gerakan sosial yang dilakukan melalui 
media sosial telah dilakukan sebelumnya dan terbukti efektif (Santoso dkk., 2018). Sebelum gerakan sosial ini dilakukan di khalayak ramai, hal ini termasuk penting untuk dilakukan di kalangan remaja, hanya saja dengan cara atau metode yang berbeda, misalnya melalui pendidikan atau dijadikan sebagai materi pembelajaran dengan media tertentu, dengan begitu pemahaman mengenai pelecehan seksual sudah dapat tertanam sejak dini.

Namun banyaknya kasus pelecehan seksual yang terjadi serta gerakan sosial yang telah dicanangkan oleh sebagian masyarakat yang sadar akan pentingnya hal ini tidak membuat masyarakat Indonesia sadar atau bahkan sekedar memahami bahwa catcalling bukanlah sekedar bersiul dan hal yang lumrah untuk dilakukan melainkan salah satu bentuk dari pelecehan seksual secara verbal yang sama sekali tidak pantas untuk dilakukan kepada sesama manusia. Adapun hal yang menjadi salah satu faktor tindakan catcalling ini tidak banyak diketahui oleh masyarakat Indonesia sebagai tindak pelecehan seksual secara verbal serta tidak membuat jera para pelakunya, yaitu karena di dalam Kitab Undang-Undang Hukum Pidana (KUHP) tindak pelecehan seksual disebut sebagai pencabulan, namun frasa pencabulan mengandung makna termasuk persetubuhan di dalamnya, sedangkan catcalling berada pada tindakan pelecehan seksual secara verbal yang masih jauh dari kata perbuatan keji atau kekerasan yang melibatkan fisik, tetapi merujuk pada istilah kesopanan dan kesusilaan, sehingga belum ada aturan pasti yang mengatur tentang batasan dan hukuman atas tindakan ini (Syaputra, 2019). Sementara dalam UndangUndang Nomor 39 Tahun 1999 tentang
Hak Asasi Manusia dalam norma hak untuk bebas dari pelecehan seksual, namun tanpa rumusan unsur tindak pidana dan ancaman pidana. Maka dari itu, dengan tidak diberlakukannya tindak pidana atau sanksi yang jelas dari tindakan tersebut, masih banyak masyarakat di luar sana yang menganggap hal ini sebagai hal yang lumrah terjadi.

Merujuk kepada kasus di atas, tindak pelecehan seksual tidak hanya dapat terjadi di kalangan orang dewasa saja, melainkan juga rentan terjadi di kalangan remaja. Melihat dari salah satu ciri remaja seperti rasa ingin tahu seksual dan coba-coba. Rasa ingin tahu seksual dan bangkitnya birahi jelas menimbulkan bentuk-bentuk perilaku seksual. Perilaku ini merupakan ciri yang normal pada perkembangan masa remaja. Akan tetapi, meskipun perilaku tersebut merupakan hal yang normal, kita masih perlu melihat masa remaja sebagai usia bermasalah. Fase remaja sebagai usia bermasalah yang dimaksud di sini adalah setiap periode perkembangan mempunyai masalahnya sendiri-sendiri, namun masalah masa remaja sering menjadi persoalan yang sulit diatasi baik oleh anak laki-laki maupun anak perempuan. Ketidakmampuan mereka untuk mengatasi sendiri masalahnya menurut cara yang mereka yakini, banyak remaja akhirnya menemukan bahwa penyelesaiannya tidak selalu sesuai dengan harapan mereka (Putro, 2017).

Orang tua/pengasuh/pendidik perlu memahami tahap perkembangan ini, sehingga ketika seorang remaja baik laki-laki atau perempuan melakukan tindakan yang tidak pantas, dalam hal ini pelecehan seksual secara verbal khususnya, dengan tanggap dapat dibatasi dengan mengedukasi remaja 
tersebut mengenai hal-hal yang seharusnya dan tidak seharusnya dilakukan. Salah satu upaya yang dapat dilakukan untuk mencegah tindak pelecehan seksual secara verbal (catcalling) terjadi pada remaja baik sebagai pelaku maupun korban, yaitu dengan memberikan edukasi mengenai hal tersebut melaui layanan bimbingan klasikal di sekolah. Bimbingan klasikal merupakan salah satu kegiatan dalam bimbingan konseling yang memiliki peran atau pengaruh cukup besar untuk meningkatkan pengetahuan peserta didik, dan dengan seiring berjalannya waktu, guru BK tentu harus dapat mengikuti perkembangan zaman, khususnya dalam hal penggunaan media pada layanan bimbingan klasikal. Media yang digunakan tentunya harus merupakan media yang mudah diakses, menarik dan sesuai karakteristik remaja.

Terdapat berbagai macam media dalam ranah pendidikan yang dapat digunakan sebagai media pembelajaran, salah satunya adalah komik.Komik merupakan media visual yang dapat digunakan sebagai media edukasi mengenai pelecehan seksual secara verbal (catcalling) karena melibatkan indera penglihatan di dalamnya. Laksono (2004) dalam penelitiannya yang berjudul Comic Strips: Media Kritik Sosial menyatakan bahwa komik merupakan bagian dari popular culture yang memberikan kesenangan bagi pembacanya.

Komik sebagai produk visual juga memiliki fungsi sebagai media dalam menyampaikan informasi. Komik sebagai media komunikasi memiliki kemampuan menyesuaikan diri yang luar biasa sehingga sering digunakan untuk berbagai macam tujuan (Setiawan, 2002). Selain itu, pada bidang pendidikan, Johana \& Widayanti (2007) menyatakan bahwa penggunaan komik sebagai media pembelajaran akan dapat lebih mudah untuk dipahami dan juga sangat efektif untuk digunakan.

Mengikuti perkembangan zaman, komik yang semakin diminati oleh banyak masyarakat adalah komik yang dipublikasikan secara digital, McCloud (2006) menyatakan bahwa saat ini situs penyedia komik digital sudah sangat banyak dan tak terbatas jumlahnya. ICv2 (2013) juga melaporkan bahwa perkembangan komik digital di dunia pada tahun 2011 dan 2012 mencapai 300\%. Kustianingsari \& Dewi (2015) juga menyatakan bahwa komik digital adalah media yang dapat memudahkan peserta didik dalam pemahaman gambar secara menyeluruh, membangun imajinasi, menuangkan ide-idenya berdasarkan pesan didapat dari komik digital, serta dapat menceritakan secara runtut isi cerita di dalamnya.

Berdasarkan hasil penelitian yang dilakukan oleh Benedicta Alodia Sansoto dan Michael Bezaleel dengan judul Perancangan Komik 360 sebagai Media Informasi tentang Pelecehan Seksual (Catcalling), didapatkan hasil bahwa masih kurangnya media kampanye atau sosialisasi tentang pelecehan seksual verbal berupa catcalling yang tidak hanya informatif tetapi juga memberikan gambaran secara netral tentang kasus pelecehan, dan komik menjadi salah satu jenis media baru yang dapat digunakan sebagai media informasi mengenai kasus catcalling (Santoso dkk., 2018).

Setelah melakukan studi pendahuluan dengan mewawancarai guru BK dan penyebaran angket pada 100 peserta didik kelas X di SMAN 59 Jakarta, diperoleh data-data sebagai berikut: Guru BK SMAN 59 Jakarta 
memiliki jam untuk menyampaikan materi di kelas setiap minggu. Media pembelajaran yang paling sering digunakan oleh guru BK sebagai media pembelajaran di kelas adalah powerpoint, pamflet, poster, film, dan hasil karya atau tugas-tugas peserta didik. Guru BK belum pernah memberikan materi dengan menggunakan komik digital sebagai media pembelajaran.

Sebanyak $77 \%$ peserta didik membaca komik untuk mengisi waktu luang, $84 \%$ peserta didik tertarik untuk membaca komik, 93\% lebih tertarik membaca komik digital dibandingkan komik biasa karena lebih efektif, 89\% peserta didik menyatakan komik digital lebih efektif digunakan sebagai media pembelajaran dibandingkan buku pelajaran, $86 \%$ peserta didik lebih termotivasi untuk belajar melalui komik digital dibandingkan buku pelajaran, dan $92 \%$ peserta didik menyatakan akan lebih cepat memahami pesan yang disampaikan melaui komik digital dibandingkan buku pelajaran.

Secara keseluruhan dari 100 peserta didik kelas $\mathrm{X}$ persentase tingkat pengetahuannya mengenai pelecehan seksual khususnya secara verbal (catcalling) adalah 37\%.

$53 \%$ dari 100 peserta didik pernah menjadi korban siulan oleh temannya sendiri, $68 \%$ diantaranya pernah menjadi korban siulan oleh orang yang tidak di kenal, $60 \%$ diantaranya pernah memberi rayuan yang berkonotasi seksual kepada orang yang tidak dikenal, 54\% diantaranya pernah melontarkan ajakan yang mendesak untuk berkencan dengan temannya sendiri, $68 \%$ diantaranya merasa pernah mendapat perlakuan catcalling dari temannya sendiri, dan $75 \%$ diantaranya merasa pernah mendapat perlakuan catcalling dari orang yang tidak dikenal.

Peserta didik yang pernah menjadi korban catcalling menyatakan bahwa terdapat dampak yang mereka rasakan dari pengalamannya tersebut, yaitu korban menjadi sering merasa cemas dan takut untuk pulang atau berpergian melewati jalan yang sama atau bahkan keluar kelas untuk sekedar pergi ke kantin, semangat untuk pergi ke sekolah serta kepercayaan diri juga menjadi menurun.

Peserta didik kelas X di SMAN 59 Jakarta diharapkan dapat memperoleh pengetahuan yang lengkap, jelas dan benar mengenai bentuk-bentuk pelecehan seksual khususnya secara verbal melalui komik digital mengenai pelecehan seksual secara verbal (catcalling), sehingga dari komik digital ini peserta didik dapat meningkatkan sikap berupa pengendalian diri untuk tidak melakukan tindak pelecehan seksual yang masih dianggap lumrah oleh sebagian masyarakat serta menyebarluaskan informasi tentang catcalling yang termasuk ke dalam salah satu bentuk pelecehan seksual dan sama sekali bukan hal yang lumrah untuk dilakukan oleh setiap individu terhadap individu lainnya.

Berdasarkan latar belakang yang sudah dijelaskan, maka peneliti ingin mengembangkan sebuah produk berupa komik digital untuk membantu peserta didik dalam meningkatkan pengetahuannya mengenai pelecehan seksual secara verbal (catcalling).

\section{Komik Digital}

McCloud (1993) di dalam bukunya yang berjudul "Understanding Comics: The Invisible Art" menjelaskan bahwa seorang seniman yang sudah sangat 
menguasai komik Will Eisner menggunakan istilah "Sequental Art" ketika mendefinisikan komik, menurutnya komik merupakan sebuah seni yang tersusun. Setiap gambar pada komik masing-masing memiliki nilai sebagai seni komik.

Pada tahun 1993, McCloud menegaskan bahwa dirinya setuju dengan Will Eisner bahwa komik adalah sebuah bentuk seni berurutan, namun McCloud lebih menspesifikasikan komik sebagai gambar-gambar dan lambang-lambang lain yang juktaposisi (berderetan/bersebalahan/berdampingan ) dalam urutan tertentu, serta memiliki tujuan untuk memberikan informasi dan/atau mencapai tanggapan estetis pembaca (Imanda, 2014).

Adapun pendapat lain mengenai komik, menurut Daryanto (2010) komik dapat juga diartikan sebagai bentuk kartun yang memiliki karakter serta menampilkan suatu cerita bergambar yang diciptakan dengan tujuan agar dapat memberikan hiburan bagi para pembacanya.

Komik dapat dikelompokkan menjadi dua jenis, yaitu komik cetak dan komik digital. Perbedaan utama antara komik cetak dan komik digital terdapat pada formatnya, pada komik digital formatnya telah diubah menjadi digital sehingga dapat juga dibaca dengan menggunakan alat elektronik (Peterson, 2011).

Lubis (2011) menjelaskan komik digital dapat diartikan sebagai gambar yang dijajarkan atau diurutkan dengan sengaja, yang pengerjaannya menggunakan bantuan komputer atau alat elektronik lainnya. Berbeda dengan komik cetak yang dikerjakan dengan cara dipindai dengan scanner, lalu diberi warna dengan menggunakan komputer, komik digital akan diterbitkan secara digital pula.

Kustianingsari \& Dewi (2015) menyampaikan bahwa komik digital memiliki pengertian yang sama dengan komik cetak begitupun dengan bentuknya, hanya saja yang membedakan adalah kemasan dan cara pengoperasiannya, komik digital dikemas dan dioperasikan dengan menggunakan aplikasi/software Flipbook serta berbentuk panel (kotak gambar) yakni mengubah berkas dengan format pdf atau gambar menjadi layaknya sebuah buku digital atau album fisik ketika dibuka setiap halamannya. Hasil akhir dari komik digital juga dapat disimpan ke dalam format .swf, .exe, dan .html.

\section{Pelecehan Seksual secara Verbal (Catcalling)}

Menurut Collier (1998) pelecehan seksual secara etimologi dapat diartikan sebagai segala macam bentuk perilaku yang berkonotasi seksual yang dilakukan secara sepihak dan tidak diharapkan oleh orang yang menjadi sasaran, dan penolakan atau penerimaan korban atas perilaku tersebut dijadikan sebagai bahan pertimbangan baik secara implisit maupun eksplisit.

Sedangkan menurut Guntoro Utamadi \& Paramitha Utamadi (2001), secara umum pelecehan seksual adalah adalah segala macam bentuk perilaku yang berkonotasi atau mengarah kepada hal-hal seksual yang dilakukan secara sepihak dan tidak diharapkan oleh orang yang menjadi sasaran, sehingga menimbulkan reaksi negatif seperti malu, marah, benci, tersinggung, dan sebagainya pada diri individu yang menjadi korban pelecehan tersebut. Secara operasional, pelecehan seksual di 
definisikan berdasarkan hukum sebagai adanya bentuk dari diskriminasi seksual.

Pelecehan seksual bisa terjadi dimana saja dan kapan saja, meskipun pada umumnya para korban pelecehan seksual adalah kaum perempuan, namun hal ini tidak berarti bahwa kaum laki-laki kebal (tidak pernah mengalami) terhadap pelecehan seksual (N. L. Lubis, 2013). Pelecehaan seksual atau pemerkosaan pada umumnya dilakukan oleh orang yang sudah sangat dikenal korban, misalnya teman dekat, kekasih, saudara, ayah (tiri maupun kandung), guru, pemuka agama dan atasan. Beberapa kasus lainnya, pelecehan seksual juga dilakukan oleh orang yang baru di kenal dan semula nampak sebagai orang baikbaik yang menawarkan bantuan, misalnya mengantarkan korban ke suatu tempat.

Berdasarkan beberapa pengertian di atas, maka dapat disimpulkan bahwa pelecehan seksual merupakan sebuah tindakan atau perbuatan yang berhubungan dengan dorongan seksual yang bersifat mengganggu dan juga merugikan orang lain. Biasanya dilakukan oleh seorang atau sekelompok laki-laki kepada seorang atau sekelompok perempuan, namun tidak jarang pelecehan seksual terjadi pada kaum laki-laki, baik secara verbal maupun nonverbal.

Menurut Chhun (2011) cukup sulit untuk mencari definisi yang tepat dari catcalling, namun catcalling dapat diartikan sebagai penggunaan bahasa yang kasar, ekspresi secara verbal dan secara nonverbal yang terjadi di ruang publik seperti jalanan, pemberhentian bus, atau di pinggir jalan. Catcall merupakan kata dasar dari catcalling, Oxford Dictionaries mendifinisikan catcall sebagai siulan kencang atau komentar yang bersifat seksual yang dilakukan oleh seorang laki-laki kepada seorang perempuan yang lewat. Catcalling adalah sebuah bentuk pelecehan seksual, atau atensi seksual yang tidak diinginkan, atau juga dapat dikatakan sebagai pelecehan yang dilakukan oleh orang asing, karena korban dan pelaku biasanya tidak mengenal satu sama lain (Fairchild \& Rudman, 2008).

Suryandaru (2007) menyatakan bahwa sampai saat ini di Indonesia belum ada padanan kata yang pasti untuk menjelaskan tentang catcalling, pelecehan seksual secara verbal adalah kata yang paling mendekati dapat diartikan dengan perbuatan seperti melontarkan kata yang berkonotasi seksual maupun perilaku genit atau centil kepada orang lain yang akhirnya menimbulkan rasa tidak nyaman bagi yang menerima. Kinasih (2007) mengatakan bahwa catcalling termasuk ke dalam pelecehan seksual secara verbal yang terjadi kepada seseorang tanpa kesukarelaan orang tersebut.

Catcalling memiliki karakteristik pelecehan yang dilakukan oleh orang asing atau pelecehan di jalanan antara lain "penggunaan bahasa kasar, ekspresi verbal, dan ekspresi nonverbal yang terjadi di area publik seperti jalan, trotoar, atau pemberhentian bus" (Chhun, 2011 as cited in Farmer \& Jordan, 2017).

N. K. Endah Triwijati (Fakultas Psikologi Universitas Surabaya, Savy Amira Women's Crisis Center) menjelaskan dari sisi tinjauan psikologis, wujud pelecehan seksual verbal lebih dilakukan dengan wujud ucapan/perkataan yang ditujukan pada orang lain namun mengarah pada sesuatu yang berkaitan dengan seksual atau yang 
biasa disebut perilaku catcalling (Harendza dkk., 2018).

Sedangkan menurut Chhun (2011) catcalling dapat digunakan sebagai pengungkapan ekspresi secara verbal maupun nonverbal. Contoh dari catcalling sebagai ekspresi verbal meliputi memanggil seseorang dengan sebutan lain, ajakan untuk berbuat cabul, siulan nakal, serta komentar mengenai penampilan fisik seseorang. Contoh dari catcalling sebagai ekspresi nonverbal meliputi sebuah kerlingan mata, kedipan mata, gerakan tubuh, atau penggunaan isyarat untuk menilai penampilan fisik seseorang.

Terdapat tiga dampak pelecehan seksual yang ditimbulkan menurut O’Donohue (N. L. Lubis, 2013), sebagai berikut:

1. Dampak pada psikologis seperti menurunnya harga diri, menurunnya kepercayaan diri, depresi, kecemasan dan ketakutan.

2. Dampak pada kondisi fisik seperti sakit kepala, gangguan makan, gangguan pencernaan, menurun atau bertambahnya berat badan dan menggigil tanpa sebab yang jelas.

3. Dampak pada pekerjaan korban pelecehan seksual seperti menurunnya kepuasan kerja, semangat kerja dan tingkat kepercayaan diri dalam bekerja.

Berdasarkan penelitian yang dilakukan oleh Farmer \& Jordan (2017) sebagian besar perempuan menjelaskan teknik dan strategi yang dapat dilakukan untuk menghindari tindakan catcalling yang cukup berisiko. Strategi-strategi ini akan memungkinkan mereka merasa tidak mudah menjadi korban dalam sebuah kejahatan, yaitu:

1. Menjaga cara berpakian atau berpakaian tertutup sampai bawah.
2. Memperhatikan cara berjalan agar tidak terlihat seperti menggoda.

3. Tidak perlu bersikap terlalu ramah dengan melihat bagaimana sikap orang tersebut, terlebih untuk orang yang tidak dikenal.

4. Posisikan diri untuk terlihat angkuh, seperti menegakkan bahu atau menggunakan masker penutup mulut dan hidung.

\section{METODE PENELITIAN}

Penelitian ini menggunakan metode Research and Development (R\&D) dan hasil akhir dari penelitian ini adalah sebuah produk berupa komik digital yang dikembangkan dengan menggunakan model penelitian ADDIE (Analysis, Design, Development, Implementation, Evaluation). Akan tetapi, penelitian ini hanya dilakukan sampai pada tahap pengembangan.

Tahap analisis, pada tahap ini peneliti melakukan wawancara dengan guru BK dan menyebarkan angket kepada peserta didik kelas X sebanyak 100 orang guna merumuskan tujuan berdasarkan kesenjangan yang terjadi di sekolah dengan keadaan yang seharusnya.

Tahap desain, pada tahap ini peneliti mendesain komik digital mengenai pelecehan seksual secara verbal (catcalling).

Tahap pengembangan, pada tahap ini peneliti membuat komik digital mengenai pelecehan seksual secara verbal (catcalling). Pembuatan komik digital dikerjakan oleh peneliti sendiri dengan dibantu oleh ahli media untukmenyempurnakan desain komik digital.

Branch (2010) menjelaskan bahwa jumlah yang optimal untuk melakukan uji kelompok kecil yaitu antara $8-20$ 
responden. Maka dari itu, uji pilot yang dilakukan pada penelitian ini menggunakan sampel sebanyak 10 peserta didik. Sebelum melakukan uji pilot, peneliti telah melakukan evaluasi formatif kepada ahli media dan ahli materi.

Teknik pengumpulan data pada penelitian ini dilakukan menggunakan angket dan wawancara. Terdapat dua angket yang digunakan pada penelitian ini; pertama angket berupa skala untuk mengukur penggunaan komik digital sebagai media pembelajaran di sekolah dan kedua, angket untuk mengetahui kebutuhan terhadap informasi yang akan diberikan kepada peserta didik.

\section{HASIL PENELITIAN}

Pengembangan ini menghasilkan sebuah media bimbingan klasikal berupa komik digital berjudul "Ketika 'Hey Cantik!' Menjadi Problematik". Materi yang dijelaskan dalam komik digital mengenai pelecehan seksual secara verbal (catcalling).

Hasil akhir dari pengembangan media ini berupa komik digital yang siap digunakan untuk mendukung kegiatan bimbingan klasikal pada layanan dasar bimbingan dan konseling di SMAN 59 Jakarta.

Selanjutnya peneliti melakukan evaluasi formatif terhadap media yang telah dikembangkan. Evaluasi formatif dilakukan oleh ahli media dan ahli materi. Berikut adalah kriteria penilaian kelayakan media menurut Arikunto (2011):

\begin{tabular}{cc}
\hline Persentase & Interpretasi \\
Pencapaian & \\
\hline $81-100 \%$ & Sangat Layak \\
$61-80 \%$ & Layak \\
$41-60 \%$ & Cukup Layak \\
\hline
\end{tabular}

21-40\%
0-20\%

\begin{tabular}{lcccc}
\hline Aspek & $\begin{array}{c}\text { Ite } \\
\mathrm{m}\end{array}$ & $\begin{array}{c}\sum_{\text {Sko }} \\
\mathrm{r}\end{array}$ & $\begin{array}{c}\text { Kriteri } \\
\mathrm{a}\end{array}$ \\
\hline Desain & 5 & 16 & & \\
Isi & 5 & 14 & 74 & Layak \\
Bahasa & 4 & 13 & $\%$ & \\
Ilustras & 4 & 10 & & \\
$\mathrm{i}$ & & & \\
\multicolumn{4}{l}{ Tabel 2. Hasil Uji Kelayakan Media }
\end{tabular}

Kesimpulan hasil penilaian uji kelayakan media yang dilakukan secara keseluruhan mencapai $74 \%$ dan termasuk dalam kategori layak. Keunggulan dari komik digital ini menurut ahli media yaitu menarik dan tidak membosankan. Adapun kelemahan dari komik digital ini yaitu teks pada balon teks tidak kontras. Namun, secara keseluruhan komik digital ini dinyatakan layak untuk digunakan sebagai media pembelajaran.

Uji kelayakan materi yang dilakukan oleh ahli materi yaitu Ibu Dra. Michiko Mamesah, M.Psi. selaku dosen Program Studi Bimbingan dan Konseling Universitas Negeri Jakarta menunjukkan hasil sebagai berikut:

\begin{tabular}{lcccc}
\hline Aspek & $\begin{array}{c}\text { Ite } \\
\mathrm{m}\end{array}$ & $\begin{array}{c}\sum_{\text {Sko }} \\
\mathrm{r}\end{array}$ & $\begin{array}{c}\text { Kriteri } \\
\mathrm{a}\end{array}$ \\
\hline Materi & 5 & 20 & 90 & Sangat \\
Isi & 5 & 20 & $\%$ & Layak \\
Bahasa & 5 & 16 & &
\end{tabular}




\section{Ilustras $\quad 3 \quad 9$} i

Tabel 3. Hasil Uji Kelayakan Materi

Berdasarkan analisis penilaian yang dilakukan oleh ahli materi secara keseluruhan mencapai $90 \%$ dan termasuk dalam kategori sangat layak. Keunggulan dari komik digital ini menurut ahli materi yaitu materi yang disampaikan sudah sangat sesuai. Adapun kelemahan dari komik digital ini yaitu ilustrasi yang kurang menggambarkan ekspresi tokoh. Namun, secara keseluruhan komik digital ini dinyatakan layak untuk digunakan sebagai media pembelajaran.

Setelah melakukan uji kelayakan media dan materi, peneliti melakukan perubahan media sesuai dengan saran yang diberikan oleh ahli media dan ahli materi. Selanjutnya, peneliti melakukan uji pilot untuk mengukur ketertarikan peserta didik terhadap komik digital, mulai dari desain komik digital, isi materi yang terdapat di dalamnya, bahasa yang digunakan, dan ilustrasi yang ditampilkan dalam komik digital. Berikut adalah hasil uji pilot untuk penilaian media kepada peserta didik:

\begin{tabular}{lcccc}
\hline Aspek & $\begin{array}{c}\text { Ite } \\
\mathrm{m}\end{array}$ & $\begin{array}{c}\sum_{\text {Sko }} \\
\mathrm{r}\end{array}$ & $\begin{array}{c}\text { Kriteri } \\
\mathrm{a}\end{array}$ \\
\hline Desain & 6 & 213 & & \\
Isi & 3 & 110 & 87 & Sangat \\
Bahasa & 4 & 132 & $\%$ & Layak \\
Ilustras & 2 & 68 & & \\
$\mathrm{i}$ & & & & \\
\hline
\end{tabular}

Tabel 4.Hasil Uji Pilot Media

Berdasarkan hasil uji coba kepada peserta didik secara keseluruhan mencapai hasil $87 \%$, sehingga komik digital termasuk ke dalam kategori sangat layak untuk digunakan sebagai media pembelajaran bagi peserta didik.
Berikut adalah hasil uji pilot untuk mengukur ketercapaian tujuan instruksional:

\begin{tabular}{lccc}
\hline Nama & $\begin{array}{c}\text { Skor } \\
(1)\end{array}$ & $\begin{array}{c}\text { Skor } \\
(2)\end{array}$ & $\begin{array}{c}\% \\
\text { Perubahan } \\
\text { Skor }\end{array}$ \\
\hline TAP & 80 & 80 & $0 \%$ \\
MFR & 70 & 100 & $30 \%$ \\
KFH & 30 & 100 & $70 \%$ \\
MP & 20 & 80 & $60 \%$ \\
AEG & 30 & 90 & $60 \%$ \\
DS & 50 & 100 & $50 \%$ \\
DAA & 70 & 70 & $0 \%$ \\
NK & 30 & 100 & $70 \%$ \\
JSU & 40 & 70 & $30 \%$ \\
FAS & 60 & 80 & $20 \%$ \\
Rata-rata Perubahan & $39 \%$ \\
Skor & \multicolumn{3}{l}{} \\
\hline
\end{tabular}

Tabel 5. Hasil Uji Pilot Ketercapa1ian

Tujuan Instruksional

Tabel di atas menunjukkan hasil ketercapaian tujuan instruksional peserta didik sebelum dan sesudah membaca komik digital serta mengerjakan tes pengetahuan. Berdasarkan hasil perhitungan tersebut dapat dikatakan peserta didik mengalami peningkatan pengetahuan mengenai pelecehan seksual secara verbal (catcalling) sebesar 39\% setelah membaca komik digital.

Pengembangan media pembelajaran berupa komik digital mengenai pelecehan seksual secara verbal (catcalling) untuk peserta didik ini memiliki keterbatasan sebagai berikut:

1. Pengembangan media dalam penelitian ini hanya berhenti pada tahap pengembangan. Tahap implementasi dan evaluasi tidak dilakukan karena keterbatasan waktu dan juga biaya. 
2. Penilaian media yang dilakukan hanya sebatas pada ahli medi dan ahli materi saja. Media komik digital ini belum dilakukan penilaian oleh ahli bahasa.

3. Penelitian ini hanya diujikan kepada kelompok kecil untuk mengukur hasil pada ranah afektif. Hal ini dikarenakan pengembangan komik digital berfokus pada pemberian pengetahuan mengenai pelecehan seksual secara verbal (catcalling).

4. Masukan dari ahli materi untuk memperbaiki ilustrasi gambar agar lebih menggambarkan ekspresi tokoh pada komik digital tidak dapat dilakukan dikarenakan keterbatasan waktu yang dimiliki.

\section{KESIMPULAN}

Penelitian mengenai pengembangan komik digital mengenai pelecehan seksual secara verbal (catcalling) melalui bimbingan klasikal pada peserta didik SMAN 59 Jakarta telah selesai dilakukan. Langkah awal penelitian ini adalah peneliti melakukan studi pendahuluan untuk menganalisis potensi dan masalah serta melihat apakah terdapat kesenjangan antara keadaan yang seharusnya dengan keadaan yang ada di lingkungan sekolah.Setelah melakukan studi pendahuluan, secara keseluruhan dari 100 peserta didik kelas $\mathrm{X}$ persentase tingkat pengetahuannya mengenai pelecehan seksual khususnya secara verbal (catcalling) adalah $37 \%$.

Guru BK di sekolah tersebut juga mengatakan bahwa penting bagi peserta didik kelas $\mathrm{X}$ untuk mendapatkan materi mengenai pelecehan seksual karena pada usianya saat ini peserta didik sudah mulai memiliki ketertarikan dengan lawan jenis, maka dari itu peserta didik perlu mengetahui bentuk-bentuk dari pelecehan seksual.Komik digital merupakan salah satu media yang diminati oleh peserta didik, terlebih lagi guru BK di sekolah tersebut belum pernah menggunakan komik digital sebagai media pembelajaran.

Tahap selanjutnya, peneliti mulai menyusun rencana desain, cerita, serta materi apa saja yang akan ditampilkan dalam komik digital. Maka dari itu hasil akhir dari penelitian ini merupakan komik digital mengenai pelecehan seksual secara verbal (catcalling) yang berjudul Ketika "Hey, Cantik!" menjadi Problematik, untuk meningkatkan pengetahuan peserta didik.

Selanjutnya, komik digital dikembangkan oleh peneliti dengan dibantu oleh ahli media untuk menyempurnakan desain komik digital.Setelah komik digital selesai dikembangkan, peneliti melakukan tahap uji validitas dengan ahli media, ahli materi, serta uji pilot dengan 10 peserta didik SMAN 59 Jakarta. Hasil uji validitas yang didapatkan dengan ahli media adalah sebesar $74 \%$ yang termasuk dalam kategori layak dan ahli materi sebesar $90 \%$ yang termasuk dalam kategori sangat layak. Lalu dari uji pilot terhadap penilaian media dengan 10 peserta didik secara keseluruhan memperoleh hasil sebesar $87 \%$ yang termasuk dalam kategori sangat layak. Sedangkan dari uji coba ketercapaian tujuan instruksional menggunakan soal tes pengetahuan memperoleh hasil sebesar $87 \%$ yang termasuk dalam kategori sangat layak, artinya tujuan instruksional telah tercapai. Berdasarkan data-data tesebut, komik digital mengenai pelecehan seksual secara verbal (catcalling) yang telah dikembangkan oleh peneliti memperoleh hasil keseluruhan sebesar $83,67 \%$ dengan kategori sangat layak 
untuk digunakan sebagai media pembelajaran.

\section{SARAN}

1. Program Studi Bimbingan dan Konseling

Komik digital mengenai pelecehan seksual secara verbal (catcalling) dapat menjadi pertimbangan sebagai media yang memberikan informasi terkait tindak pelecehan seksual, mulai dari pengertian pelecehan seksual khususnya secara verbal (catcalling), bagaimana macam-macam atau karakteristiknya, dampak dari tindakan tersebut, hingga bagaimana cara untuk mengatasi hal tersebut.

Komik digital ini dapat digunakan sebagai media pendukung pada mata kuliah Konseling Multikultural ketika membahas materi terkait orientasi seksual. Mahasiswa perlu mengetahui bahwa catcalling merupakan salah satu contoh diskriminasi gender yang ada di lingkungan masyarakat.

Mahasiswa dapat menggunakan komik digital ini untuk berdiskusi tentang bagaimana pengaruh atau peran keluarga terhadap fenomena catcalling yang terjadi khususnya di kalangan remaja pada mata kuliah Konseling Keluarga.

Komik digital ini dapat digunakan sebagai media agar mahasiswa dapat mengetahui pengaruh kesehatan mental terhadap pelaku ataupun korban dari catcalling pada mata kuliah Kesehatan Mental.

Komik digital ini dapat dijadikan sebagai media atau alat bantu bagi konseli yang memiliki pengalaman terkait tindak pelecehan seksual secara verbal (catcalling) pada mata kuliah Praktikum Konseling Individual.

Komik digital ini juga dapat dijadikan sebagai referensi bagi mahasiswa program studi bimbingan dan konseling untuk mengembangkan media pembelajaran.

2. Guru Bimbingan dan Konseling

Mengingat bahwa materi mengenai pelecehan seksual secara verbal khususnya (catcalling) sangat penting untuk dipelajari, maka diharapkan guru BK memiliki pengetahuan yang cukup baik mengenai pelecehan seksual sebelum memberikan informasi tersebut kepada peserta didik karena komik digital ini dikembangkan hanya sebagai penunjang dalam menampilkan materi dan gambaran atau ilustrasi pada saat bimbingan klasikal dilakukan.

3. Peneliti Selanjutnya

Penelitian ini dapat dijadikan sebagai referensi bagi peneliti selanjutnya yang ingin meneliti lebih luas tentang hal-hal yang berkaitan dengan pelecehan seksual secara verbal (catcalling) serta dapat melanjutkan tahapan pengembangan model ADDIE pada tahap implementasi dan evaluasi agar dapat diketahui efektivitas media dalam layanan bimbingan klasikal dan mampu memperluas tujuan instruksional peserta didik hingga sampai ranah afektif dan psikomotorik.

Berdasarkan

beberapa keterbatasan yang ada pada penelitian ini, maka diharapkan peneliti selanjutnya dapat mengembangkan produk dengan memperhatikan beberapa hal yang masih terbilang kurang dalam penelitian ini agar 
produk yang dihasilkan dapat lebih optimal.

\section{DAFTAR PUSTAKA}

Arikunto, S. (2011). Prosedur Penelitian: Suatu Pendekatan Praktik (Rev. VI, C). Rineka Cipta.

Branch, R. M. (2010). Instructional design: The ADDIE approach. Instructional Design: The ADDIE Approach, $1-203$. https://doi.org/10.1007/978-0-38709506-6

Chhun, B. (2011). Catcalls: Protected Speech or Fighting Words. Thomas Jefferson Law Review, 33, 273295.

Collier, R. (1998). Pelecehan Seksual: Hubungan Dominasi Mayoritas dan Minoritas (Cet.1). Tiara Wacana.

Daryanto. (2010). Media Pembalajaran. Satu Nusa.

Fairchild, K., \& Rudman, L. A. (2008). Everyday Stranger Harassment and Women's Objectification. Springer Science+Business Media, 21, 338$357 . \quad$ https://doi.org/DOI 10.1007/s11211-008-0073-0

Farmer, O., \& Jordan, S. S. (2017). Experiences of Women Coping With Catcalling Experiences in New York City: A Pilot Study. Journal of Feminist Family Therapy, 29(4), 2015-2225.

Harendza, J. G., H, D. D., S, M. A., \& Petra, U. K. (2018). Perancangan Kampanye Sosial "JAGOAN."

ICv2. (2013). Digital Comics Nearly Tripled in 2012.

Imanda, T. (2014). 'Komik Indonesia itu Maju': Tantangan Komikus Underground Indonesia.
Antropologi Indonesia, O(69), 4762. https://doi.org/10.7454/ai.v0i69.34 44

Johana, M., \& Widayanti, A. (2007). Komik sebagai Media Pengajaran Bahasa yang Komunikatif bagi Siswa SMP. Lembaran Ilmu Pendidikan, 36(1), 28-34.

Kinasih, S. E. (2007). Penegakan HAM dan Perlindungan Terhadap Korban Pelecehan Seksual. Jurnal Masyarakat dan Kebudayaan Politik Universitas Airlangga, 20(4), 307-312.

Kustianingsari, N., \& Dewi, U. (2015). Pengembangan Media Komik Digital Pada Mata Pelajaran Bahasa Indonesia Tema Lingkungan Sahabat Kita Materi Teks Cerita Manusia dan Lingkungan Untuk Siswa Kelas V SDN Putat Jaya III/379 Surabaya. Jurnal Mahasiswa Teknologi Pendidikan, 6(2), 1-9.

Laksono, A. (2004). Comic Strips: Media Kritik Sosial. Jurnal Sastra dan Bahasa, 2(2), 183-193.

Lubis, I. (2011). Sejarah Komik Menuju Masa Depan. SlideShare.

Lubis, N. L. (2013). Psikologi Kespro: Wanita \& Perkembangan Reproduksinya. Kencana Prenada Media Grup.

Martin, J. (2018). Budaya Catcalling (Pelecehan Seksual). Rifka Annisa.

McCloud, S. (1993). Understanding Comics (The Invisible Art) By Scott McCloud.pdf (hal. 215).

McCloud, S. (2006). Making Comics. William Morrow Paperbacks.

O'Leary, C. (2016). Catcalling as a" Double Edged Sword ": 
Midwestern Women, Their Experiences, and the Implications of Men 's Catcalling Behaviors.

Peterson, R. S. (2011). Comics, Manga, and Graphic Novels: A History of Graphic Narratives. Praeger Publisher.

Priherdityo, E. (2016). Pelecehan Seksual Verbal Dianggap Lumrah di Indonesia. CNN Indonesia.

Putro, K. Z. (2017). Memahami Ciri dan Tugas Perkembangan Masa Remaja. 17, 25-32.

Santoso, B. A., Bezaleel, M., Studi, P., Komunikasi, D., Informasi, F. T., Kristen, U., \& Wacana, S. (2018). Perancangan Komik 360 sebagai Media Informasi tentang Pelecehan Seksual Cat Calling. Andharupa: Jurnal Desain Komunikasi Visual \& Multimedia, 4(1), 14-24.

Setiawan, M. N. (2002). Menakar Panji Koming: Tafsiran Komik Karya Dwi Koendoro pada Masa Reformasi 1999. Kompas.

Sumera, M. (2013). Perbuatan Kekerasan/Pelecehan Seksual terhadap Perempuan. Lex et Societatis, Vol. I/No.(3), 135-146.

Supanto. (2004). Pelecehan Seksual sebagai Kekerasan Gender: Antisipasi Hukum Pidana. XX(3), 288-310.

Suryandaru, Y. S. (2007). Pelecehan Seksual Melalui Media Massa. Jurnal Masyarakat dan Kebudayaan Politik Universitas Airlangga, 20(4), 266-278.

Syaputra, I. D. (2019). Tindak Kejahatan "Catcalling" di Indonesia, Bagaimana Hukum Mengatur? Kompasiana.

Utamadi, G., \& Utamadi, P. (2001).
Pelecehan Seksual? Hiiii... Seraam! Kompas. 


\section{LAMPIRAN}

\section{Gambar Cover}

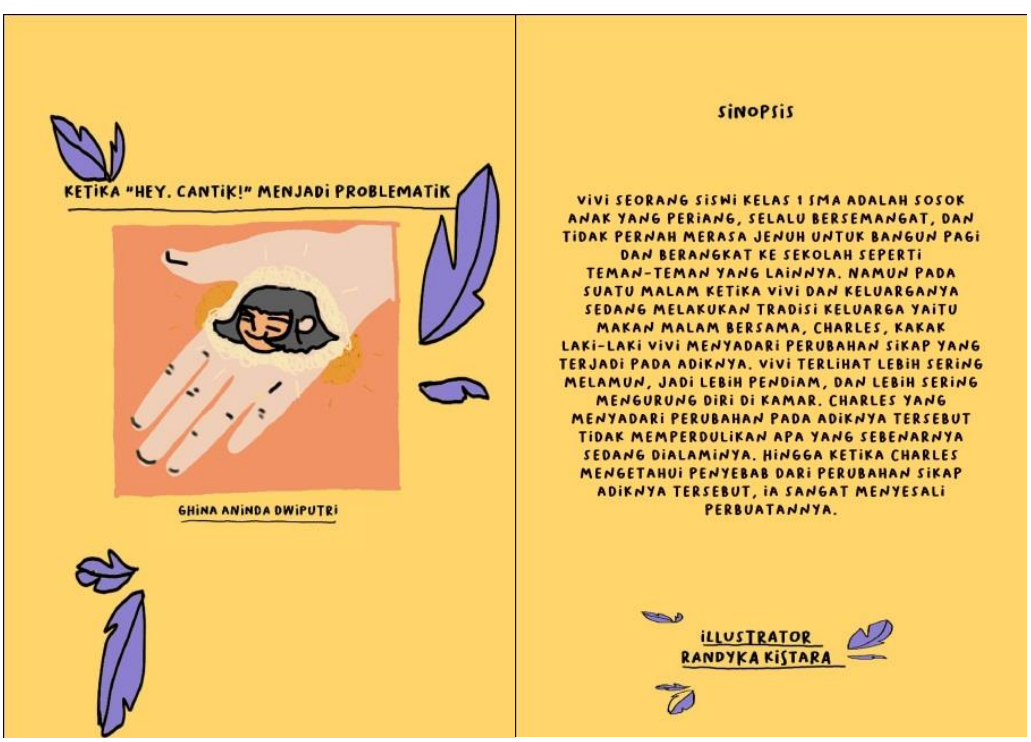

Gambar 1. Cover Bagian Depan (Kiri) dan Belakang (Kanan)

\section{Gambar Isi}
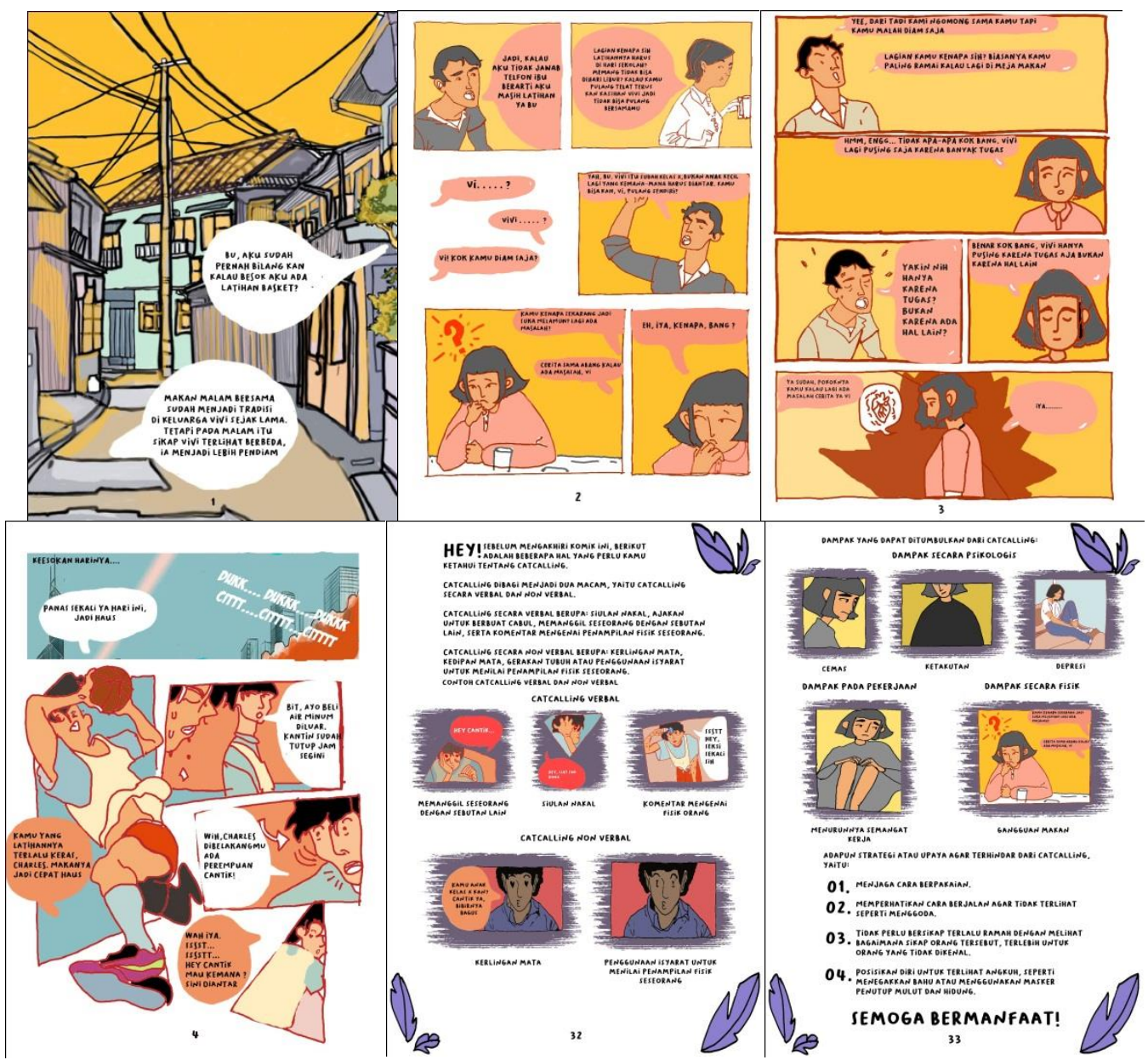

Gambar 2. Isi Komik 